\title{
ASIMILASI SPEKTRUM PERADABAN ISLAM DAN KEBERISLAMAN DI INDIA
}

\author{
Sadari \\ Institut Agama Islam Shalahuddin Al-Ayyubi (INISA) \\ Tambun-Bekasi \\ arifahmikhan@gmail.com
}

\begin{abstract}
Abstrak
Setiap Negara memiliki ke-khas-an, untuk itu senantiasa memiliki latar pembentukan tertentu, sejarah, dan bahkan kejadian spesifik yang menjadikannya berbeda dengan lainnya. Tidak lepas dari asumsi tersebut adalah keberagamaan suatu masyarakat di Negara tertentu, termasuk keislaman di India. Sejarah merekam bagaimana dinamika keislaman di India sangatlah dinamis dan kadang-kadang dramatis. Mulai dari penjelajahan biasa sembari dakwah, berdagang, sampai penaklukkan pernah mewarnai kehidupan Muslim India di masa silam. Lalu, yang namanya kenangan betapa pun memiliki pengaruh terhadap kebiasaan Muslim hari ini di wilayah yang sekarang dikenal sebagai Negara India. Artikel ini mencoba untuk menelusuri bagaimana pranata Islam di Negara tersebut, evolusi peradabannya, hingga puncak asimilasinya pada abad ke21. Artikel ini menemukan bahwa titik terbaru dari adanya proses interaksi yang panjang antara Islam dan tradisi-tradisi lainnya di India bisa dilihat dari tiga bidang yakni: ilmu pengetahuan, seni bangunan, dan bahasa.
\end{abstract}

Kata Kunci: pranata; Islam; peradaban; dinasti; India 


\section{A. Pendahuluan}

Jika akar sejarah Indonesia, seperti dijelaskan Denys Lombard, tidak bisa lepas dari tradisi Hindu-India, Islam China, dan modernitas Barat, maka dalam kasus yang sama, India tentu memiliki ceritanya sendiri. Secara umum, bicara sejarah India, maka bicara tentang dua bangsa besar yakni Dravida dan Aria. Sebelum nantinya membahas lebih fokus pada Islam dan Keislaman di India, bentuknya, persilangan wacana, dan interaksi praktis masyarakatnya, artikel ini akan terlebih dulu memaparkan isu seputar India dalam potret kesejarahannya sebagai alas penelitian.

Peradaban di India dimulai secara kasar pada sekitar 6000-5000 tahun SM. ${ }^{1}$ Adalah ditandai dengan datangnya bangsa Dravida dari Asia Barat. Mereka datang ke India dengan membawa kepercayaan bahwa ihwal ketuhanan itu abstrak. ${ }^{2}$ Selama ratusan tahun bangsa Dravida menguasai India, termasuk kepercayaannya tadi sampai akhirnya pada 4000 tahun SM, mereka memiliki teman baru dari bangsa dan budaya lain. ${ }^{3}$

Teman baru tersebut tiba di India dengan membawa kepercayaan yang berbeda sama sekali dengan mereka. Teman baru ini tidak menaruh kepercayaan terhadap tuhan yang abstrak, tetapi yang ada justru sebaliknya, Tuhan itu konkret seperti api, matahari, pohon, angin, dan semacamnya. Kemudian karena mereka hidup dan tinggal di ruang sosial yang sama, kontestasipun pecah. Dipicu dengan adanya perbedaan kepercayaan, mereka dan teman baru itu terlibat pertentangan yang tidak sederhana, mulai dari rebutan pengikut sampai kekuasaan.

${ }^{1}$ Sebelum bangsa Dravida, sudah ada bangsa Negroid dan Austroloid yang menepati wilayah India, tetapi sejarah mereka tidak banyak diketahui.

2 Abdul Manan Talib, Bangladeshe Islam (Dhaka: Adhunik Prokashani, 1980), 15-17. Kemudian bangsa Mongolia juga datang ke India Timur, terdiri atas beberapa suku; diantaranya Shautal, Rajbongshi, Garo, Khasia, Cakma, Mog, Naga, dan lain-lain. Lihat, Mansur Musa, Bangladesh (Dhaka: Department of Bangla, Dhaka University, 1974), 244-245.

3 Sadari, et.al, "Religious Local Wisdom For Strengthening Social Harmony: Study in Banyumas Indonesia and New Delhi India", in Proceedings of the 2nd International Colloquium on Interdisciplinary Islamic Studies (ICIIS) in Conjunction with the 3rd International Conference on Quran and Hadith Studies (ICONQUHAS), 2020, 7-8. 
Singkat cerita, karena bangsa yang baru datang di muka memiliki kekuatan sedikit lebih kuat ketimbang bangsa Dravida, maka bangsa Dravida harus menelan kekalahannya. Tidak sedikit pengikut kepercayaan bangsa Dravida berbelok arah dan memilih untuk mengikut kepercayaan si tamu. Ada banyak faktor tentu di dalamnya, baik itu ekonomi atau pun akal sehat. Yang jelas pertentangan ini memuncak pada lahirnya Kasta Sudra dengan ketuhanan abstrak sebagai kepercayaan yang melekat dalam diri mereka. Tamu yang berhasil menggeser bangsa Dravida sebagai pribumi ini tidak lain adalah bangsa Arya dari Persia.

Bangsa Arya ini menaruh kepercayaan pada api, matahari, pohon, angin, dan semacamnya. Jadi, bagi mereka dalam entitasentitas tersebut ada ruh luhur yang bersemayam, sehingga patut dan penting untuk disembah. Dalam upacara penyembahan, tidak jarang masyarakat Arya ini menjadikan manusia sebagai tumbal. Anggapannya sebagai ganti atas sesuatu atau pemicu dari permohonan tertentu. Model kepercayaan seperti inilah yang banyak menyebar sejak tahun $4000 \mathrm{SM}$, menggeser kepercaayan dominan sebelumnya yang lebih kepada ketuhanan abstrak.

Seiring bergantinya musim, bergesernya gaya hidup masyarakat, dan pola interaksi antarsesama penganut kepercayaan, pada 599 SM bumi India kembali dihibur dengan datangnya kepercayaan baru yang boleh dikata lebih terstruktur. Yaitu kepercayaan Jaina yang dipelopori oleh seseorang bernama Mahawir. Kepercayaan ini-atau agama lebih mudahnyamenawarkan beberapa prinsip penting bagi pemeluknya yakni pentingnya sebuah perenungan dan meninggalkan kemewahan. Dari aras sumber pengetahuan, agama Jaina tidak memilikinya melainkan Mahawir itu sendiri. Kitab Suci ia tidak mempunyainya. Ajaran pokoknya adalah ahimsa (tidak hasad) dan sasarannya semua makhluk. Boleh disebut sebagai agama universal. Seturut semakin muncul dan mapannya beberapa kepercayaan di India, agama Jaina pada akhirnya melebur - untuk tidak menyebut dileburkan — dengan agama Hindu. ${ }^{4}$ Banyaknya kesamaan di antara keduanya merupakan salah satu hal yang paling bertanggung jawab atas itu sampai akhirnya lahirlah agama Budha pada 557 SM sebagai respons atas ajaran Hinduyang itu juga berarti Jaina.

\footnotetext{
${ }^{4}$ Lihat C. Mabel Duff, The Chronology of India: From the Earleest Times to the Beginning of the Sixteenth Century (Whitehall Gardens: Archibald Constable \& Co., 1899), 4.
} 
Agama Budha lahir dari rahim seorang yang lahir di Kapilabstu, Kaki Gunung Himalaya. Namanya Gautama atau Sidharta Gautama populernya. Agama Budha lebih fokus pada prinsip toleran, dermawan, berpikir positif, sabar yang sadar, pekerjaan yang sesuai passion, dan sebentuk penyerahan kepada Yang Maha Ada. ${ }^{5}$

Berhenti sejenak di sini, berpijak pada asumsi bahwa bagaimana kebiasaan masyarakat di daerah tertentu adalah cermin dari kecenderungan nenek moyang mereka di masa lalu, situasi politik, selera, dan sebagainya, maka sebelum membahas kecenderungan masyarakat muslim di India adalah penting untuk melihat semua yang ada di India terlebih dulu. Beberapa bagian selepas ini akan mencoba melakukan pekerjaan tersebut.

\section{B. Pranata Politik, Ekonomi, Agama dan Sosial di India 1) Situasi Politik}

Dalam potret sejarah, kerajaan besar terakhir yang bercokol di daerah India, tepatnya wilayah Barat Laut India, adalah kerajaan yang dipimpin oleh Harshavardhana. Kisaran akhir abad ke-7 $\mathrm{M}$ adalah waktu ketika kerajaan tersebut tumbuh dan berkembang. Situasi berjalan normal selama beberapa tahun masa kekuasaan Harshavardhana sampai akhirnya segalanya berubah ketika sang raja menghembuskan nafas terakhir. Seperti halnya kerajaan-kerajaan lainnya kala itu, ini dipicu oleh pertentangan-pertentangan yang muncul dari anak-anak sang raja, mulai dari rebutan wilayah kekuasaan sampai persaingan pengaruh.

Singkat kisah, sejak saat itu, menurut banyak pakar, tidak ada lagi kerajaan besar di India dan yang tersisa hanyalah kerajaan-kerajaan kecil hasil pecahan dari kerajaan Harshavardhana di Qanauj tadi. Beberapa wilayah tersebutyang sekarang sudah menjadi Negara - sejauh penelusuran penulis, antara lain Afganistan, Kashmir, Nepal, Assam, Qanauj, Sind, Bangla, Malwa, Pallva, Chalukya, Pandya, Chola, dan Chera.

5 Abdul Manan Talib, Bangladeshe Islam (Dhaka: Adhunik Prokashani, 1980), 48-49, lihat, K. Ali, History of India, Pakistan, and Bangladest (Dhaka: Ali Publication, 1980), 3-8. 
Adapun mengenai sistem pemerintahan, pada masamasa itu, mash bergaya kerajaan. Sistem ini mengandaikan adanya satu sosok pusat yang disebut raja. Raja berbeda dengan presiden dalam sistem republik. Raja lebih berkuasa atas apa pun atau dengan bahasa lainnya lebih dekat dengan istilah diktator. Raja tidak saja berada di lingkar eksekutif, tetapi legislatif, yudikatif, dan beberapa bagian penting kenegaraan lainnya. Raja adalah kerajaan itu sendiri. Suara raja, bagi negaranya, adalah suara kerajaan. Begitulah pada umumnya.

Sistem pemilihan default yang dipakai adalah keturunan atau anak dari sang raja akan menggantikannya sebagai raja. Akan tetapi, dalam situasi tertentu, bisa juga raja dipilih oleh entitas penting-yang lain selain raja-dari kerajaan yang di Dinasti Pala disebut sebagai Gopala atau Nandi Varman jika menggunakan bahasa untuk masyarakat Dinasti Pallava, Kanchi. Adapun mengenai anggota atau kementerian, tentu Raja memilikinya. Jumlahnya tergantung kebutuhan, tetapi lagi-lagi raja tidak memiliki kewajiban sama sekali untuk mendengar saran mereka. Kalau misalnya apa yang mereka sarankan masuk akal dan raja setuju, barulah suara mereka berarti. Jika tidak, maka tidak ada bedanya.

Kerajaan dibagi dalam beberapa provinsi. Kepala provinsi disebut uparika. Tugas penting uparika yaitu mempertahankan keamanan dan ketertiban provinsi. Lebih ke-peran militer jika disandingkan dengan konteks hari ini. Lalu, setiap provinsi memiliki daerah bagian yang disebut sebagai vaisaya. Setiap vaisaya memiliki kepala, namanya vaisayapati. Di bawah vaisayapati ada panchayat atau kepala desa. Sumber pendapatan negara pada masa itu berpulang pada pajak tanah, sumbangan dari tuan tanah, dan perdagangan. 


\section{2) Kondisi Ekonomi}

Di aras ekonomi, secara umum masyarakat India bisa disebut makmur, terutama dalam hal pemenuhan kebutuhan hidup. Pekerjaan utama masyarakat India adalah pertanian. Namun, ini bukan berarti tidak ada perindustrian di India. India memiliki dua negara bagian yang sengaja difokuskan ke wilayah industri, yakni Bangla dan Gujarat, dengan ekspor tekstil kapas sebagai bidang garapan prioritas. Sebagai tambahan, jika tadi di daerah pertanian, gap antar-kelas tidak terlalu nampak, maka di dua negara terakhir tadi, gapnya cukup mencolok. Tidak sedikit ada pertentangan kelas antara kelas buruh tani dan elite.

\section{3) Kondisi Agama}

Saat Islam masuk ke India, ada tiga agama yang dikenal baik oleh masyarakatnya, yakni Hindu, Jaina, dan Budha. Di antara ketiganya, Hindu adalah yang paling populer dan banyak dianut. Agama Jaina, meski dikabarkan sudah melebur dengan Hindu, tetapi di beberapa daerah, beberapa lingkaran masyarakat masih memercayainya sebagai ajaran dan tradisi yang utuh dan berbeda dengan Hindu. Adapun Budha pada masa itu-bahkan sampai saat inikurang banyak mendapatkan pengikut. Ada banyak faktor tentunya mengapa Budha memiliki kisah sendu seperti itu, baik sentimen keberagamaan atau sebatas distingsi politik. Namun yang paling jelas dari semua itu adalah fakta bahwa nyaris semua raja di India beragama Hindu, sehingga kebijakan-kebijakan yang memojokkan pemeluk Budha tidak terelakkan. Di waktu bersamaan, disebabkan oleh adanya tekanan dari elite Hindu, tidak sedikit masyarakat Budha yang mengharap akan datangnya kekuatan lain, kekuatan yang baru di luar mereka, yang bisa menyelamatkan. ${ }^{6}$

\footnotetext{
6 Internet, Truth About Dahir San, http:www.osl.cs.vivc.Edu/jamali/Sindh/story/node.
} 


\section{4) Kondisi Sosial}

Secara sosial, seperti sudah banyak dikenal, masyarakat India terbagi dalam kasta-kasta. Ada empat kasta yang memecah masyarakat India, yakni Brahmana, Ksatria, Waisya, dan Sudra. Kasta ini pula yang membedakan apa pekerjaan seseorang. Banyak dari kasta pertama berada di lingkar militer atau tentara, sedangkan kasta kedua sebagai pedagang. Pekerjaan-pekerjaan lain yang lebih umum dipegang oleh dua kasta sisanya.

Selain pekerjaan, kasta juga memiliki pengaruh luar biasa pada arus serta model pernikahan di India. Adalah tabu, bahkan melanggar tradisi, jika ada pernikahan lintas kasta. Yang ada, mereka hanya diperbolehkan untuk menikah dengan sesama kastanya.

Perempuan dari kalangan Sudra tidak boleh menikah dengan laki-laki dengan kasta Ksatria, apalagi Brahmana, kendati mereka saling mencintai. Masih tentang ini pula adalah persoalan poligami, di India banyak terjadi laki-laki menikahi banyak perempuan, tetapi perempuan sendiri tidak boleh menikah untuk kali keduanya, meski posisinya sudah janda.

\section{Interaksi Islam dan India}

Setelah menjelaskan selayang tentang India, bagian ini akan masuk pada tahapan interaksi yang pernah terjadi antara Islam dan India. Dari beragam teori tentang ini, penulis lebih nyaman untuk memetakan interaksi tersebut menjadi empat. Di bawah ini akan dijelaskan empat tahapan tersebut, yakni tahap Nabi Muhammad, Khulafaur Rasyidin dan Dinasti Umayah, Dinasti Ghazni, dan terakhir Dinasti Ghuri.

1) Interaksi pada masa Nabi Muhammad Saw

Sejauh penelusuran yang sudah dilakukan, penulis sebatas menemukan dua teori untuk menjelaskan adanya interaksi ini, yaitu beberapa pedagang yang diketahui berasal dari India dan sala satu istri nabi yang bernama hind.

Pertama lebih tentang rombongan dagang dari suku Jat yang memutuskan untuk menetap di Arab dan malah ada salah satu dari mereka yang sempat mengobati Siti Aisyah, istri Nabi. Suku Jat ini tidak lain adalah suku yang ada di India dan memiliki agenda dagang yang jalur utamanya adalah Hijaz. 
Kedua menyangkut salah satu ucapan Nabi yang menurut beberapa pakar, menyebutnya begini, "May Allah bless this Hind and the country after which she is named".

Selain itu, ada juga riwayat yang menyebut bahwa sebentar lagi akan ada pasukan yang dikirim ke India untuk meneliti lebih jauh kondisi di sana dan jika memungkinkan, Islam bisa disebarkan ke India. Riwayat ini berbunyi, “...Ada dua kelompok dari umat Nabi Muhammad Saw, yang akan selamat dari api neraka, yang pertama adalah kelompok orang-orang yang berjihad atau berperang ke Hind (India) dan yang kedua adalah kelompok tentara yang ikut bersama Nabi 'Isa Ibnu Maryam".

Untuk riwayat kedua ini, seseorang bisa pula mengamati kisah tentang salah satu raja Kadangalur dari Pantai Malabar yang rupanya sudah meyakini ajaran Islam, bahkan ada yang menyebut ia sampai datang ke Arab mengunjungi Nabi. ${ }^{9}$ Jika dikaitkan dengan fakta bahwa pada kisaran tahun 630-631 M Nabi kerap berinteraksi dengan bangsa lain melalui saling mengirim utusan, maka tidak menutup kemungkinan, interaksi di muka benar adanya.

2) Interaksi pada Khulafa' al-Rasyidin dan Dinasti Umayah

Adalah Khalifah Umar bin Khattab yang pernah mengirim pasukan ke arah India. Kala itu, 643-644 M, Umar langsung mengirim dua pasukan, dua panglima, dan dua tujuan sekaligus. Satu ke Persia, sisanya ke India. Pasukan yang pergi ke Persia dipimpin oleh Usman bin Abi al-Saqafi, sedangkan yang ke India oleh Abu al-Mughira. Pasukan terakhir dihadang oleh pasukan dari Sind (nama lain dari India). Keduanya terlibat pertempuran yang tidak seimbang dan ini menjadikan pasukan Abu al-Mughira harus menerima kekalahan.

\footnotetext{
7 Internet, Truth About Dahir San, http:www.osl.cs.vivc.Edu/jamali/Sindh/story/node.

${ }^{8}$ Muhammad Reza I Karim, Arab Jatir Itihas : History of the Arabs (Dhaka: Bangkla Academy, 1972), 63-64 dan K. P. Kaya, Muslim Missionaries in South India, terjemahan Abdul Quasem Bhuiyan Dakkhin Bharta Muslim Mishionari (Faridpur: Islamic Cultural Centre, 1980), 2-3. Sumber-sumber tentang Raja Cheraman Perumal tidak ada yang menyebutkan tahun kejadian secara pasti. Barangkali peristiwa itu terjadi sekitar tahun tersebut.

9 Muhammad Reza I Karim, Arab Jatir Itihas: History of the Arabs, (Dhaka: Bangkla Academy, 1972), 127 dan Aziz Ahamd, Studies in Islamic Culture in The Indian Environment (Oxford : Clarendon Press, 1964), 3.
} 
Ketidakseimbangan mereka berpulang pada kenyataan jika pasukan Sind lebih terlatih untuk bertempur di laut ketimbang pasukan yang dikirim oleh Umar. Sebagai tambahan, mengetahui pasukannya kalah, sejak saat itu, Umar memutuskan untuk tidak dulu mengirim pasukannya guna bertempur di laut. ${ }^{10}$

Selang beberapa tahun, setelah banyak belajar dari apa yang sudah terjadi, Umar kembali mengirim pasukannya untuk invansi ke daerah India. Kali ini, panglimanya dipegang oleh Abdullah bin Amar Rabbi. Berkat pembacaan yang cukup tajam, pasukan kiriman Umar yang kali ini berhasil menguasai Kirman. Malah, mereka bisa pula sampai ke wilayah Sizistan dan Mekran. ${ }^{11}$

Beda pemimpin, beda pula kebijakannya. Pada masa Khalifah Usman dan Ali, yang terjadi-dalam kaitannya dengan Arab dan India-lebih pada penelitian wilayah, termasuk situasi masyarakat dan semacamnya. Usman muncul dengan utusannya yang dipimpin oleh Hakim bin Jabalah. Adapun Ali dengan alHaris bin Murrah al-Abdi sebagai ketua tim risetnya. Semua utusan tersebut bertugas untuk menyelidiki adat istiadat, relasi perwilayahan, dan akses yang akan mempermudah untuk menjangkaunya kelak.

Masuk ke masa pemerintahan Umayyah, bisa dibilang interaksi antara Islam dan India cukup tegang dan berwarna. Terhitung sampai khalifah al-Walid, ada dua kejadian penting yang melibatkan Dinasti Umayyah dengan kerajaan di India, yaitu yang terjadi dengan Hajjaj bin Yusuf dan keluarganya sendiri, Muhammad bin Qasim.

${ }^{10}$ C. Mabel. Duff, The Chronology of India: From the Earleest Times to the Beginning of the Sixteenth Century, (Whitehall Gardens: Archibald Constable \& Co., 1899), 52, lihat, Hamka, Sejarah Umat Islam (Jakarta: Nusantara, 1961), 472 dan Abdul Karim, Bharatiya Upamadeshe Muslim Shashan: Muslim Rule in Indian Sub-Continent (Dhaka: Bangla Academy, 1974), 2-3.

${ }_{11}$ R. E. M. Wheller, Five Thousands Years of Pakistan (London: Cristopher Jhonson 1950), 60-61, Elliphenton (Mountstuart), The History of India: The Mohametan Periods (London: Jhon Murray, 1857), 257-259. 
Sebelum keduanya sebenarnya ada satu nama lagi-yang kala itu diutus langsung oleh Muawiyah-yakni Muhallab bin Abi Sufrah yang membawa satu pasukan, tetapi kelompok ini tidak melanjutkan perjalanan selepas di Kabul. ${ }^{12}$

Kembali ke Hajjaj dan Ibn Qasim, diceritakan bahwa Hajjaj sempat geram dengan Dahir, salah satu raja yang berkuasa di wilayah perbatasan antara India dan Persia. Lebih jelasnya karena Dahir tidak mau bertanggungjawab-atau sekadar memudahkan Hajjaj-atas tragedi yang menimpa sisa rombongan pedagang dari Arab yang telah cukup lama menetap di daerah Cylon, sekitar India dan Persia. Pada awal abad ke-8 M, memang sudah ada banyak pedagang dari Arab yang menetap untuk sementara di India, salah satunya adalah rombongan yang terserang wabah tertentu sehingga menjadikan sebagian dari mereka meninggal dan membuat sebagian lainnya harus kembali ke Arab.

Untuk mengembalikan suatu rombongan ke daerah asalnya, tentu melibatkan banyak pihak. Dari pihak tempat sisa rombongan tadi tinggal, mereka sudah dipasrahkan ke khalifah al-Walid dan akan segera mengirim mereka kembali melalui kapal plus beberapa hadiah. Di tengah perjalanan, ternyata kapal mereka dirampok di sekitar Debal. Debal boleh dibilang masuk bagian Timur dari kekuasaan Khalifah al-Walid. Hajjaj, sejak masa Khalifah Abdul Malik bin Marwan, kebetulan adalah Gubernur Jenderal di wilayah Timur. Akhirnya, mau tidak mau, dan atas himbauan dari al-Walid juga, Hajjaj harus turun tangan membela masyarakatnya yang dirampok tadi.

Apa yang ada dalam bayangan Hajjaj adalah menghubungi penguasa di wilayah Debal. Penguasa Debal tidak lain merupakan Dahir. Persis di sinilah mereka berinteraksi. Tawar menawar terjadi, tetapi hasilnya kaku. Kedua belah pihak tidak bisa mencapai titik kesepakatan, sehingga terjadilah pertentangan dan gara-gara ini, Hajjaj diandaikan untuk meyakinkan dirinya agar sesegera mungkin menaklukkan daerah dari raja Dahir tadi.

${ }^{12}$ M. Abdul Karim, "Kontribusi Muhammad bin Qasim dalam Penaklukan Sind", Thaqafiyat, Vol 2 No. 2, 2001, 124-126, Wheller, Five Thousands, 6062, dan S. M Ikram, Muslim Civilization in India, ed. Ainslie T. Embree (Net York: Columbia University Press 1964), 6-7. 
Ada beberapa pertimbangan lain, akhirnya, yang muncul dari Hajjaj untuk melegitimasi keinginannya menyerang Dahir, yaitu:

a) Dahir membantu Persia dengan pasukan yang besar ketika pasukan Arab melakukan invasi ke sana

b) Raja Dahir menolak mengembalikan para pembangkang kepada pemerintahnya

c) Terjadinya drama pembajakan ${ }^{13}$

Selepas yakin dengan apa yang akan dilakukannya, Hajjaj kemudian meminta izin ke Khalifah al-Walid untuk melakukan invasi. Al-Walid mengizinkan dan Hajjaj langsung menghubungi Muhammad bin Qasim, yang waktu itu berumur 17 tahun, untuk menyiapkan pasukan guna menyerang kerajaannya Dahir, di sekitar India. Di sini, cerita invasi diambil-alih oleh Muhammad bin Qasim. Dengan dibantu oleh Abdul Aswad Janm, Ibn Qasim menyiapkan 15000 pasukan, 6000 pasukan berkuda, 6000 pasukan unta, dan sisanya pasukan yang bagian mengangkut alatalat perlengkapan perang yang berat. ${ }^{14}$ Ibn Qasim berangkat menyerang pada $708 \mathrm{M}^{15}$ Siraj dan Mekram adalah jalur yang dipilih mereka untuk sampai ke Debal.

Selain itu, yang menarik, Ibn Qasim juga dengan cakapnya berhasil mengumpulkan pasukan-pasukan tambahan di sepanjang perjalanan. Ibn Qasim menyasar beberapa suku yang secara sosial tertindas. Kebanyakan dari suku dengan kasta yang rendah. Mereka dioptimalkan sebagai penunjuk jalan. ${ }^{16}$ Ketika melintasi perkampungan, Ibn Qasim menawarkan kepada masyarakat kampung tiga pilihan: masuk Islam, membayar pajak, atau perang. Perang adalah pilihan terakhir.

${ }^{13}$ Henry Beveridge, A Comprehensive Hostory of India I (London: Blackie \& Son, 1862), 41 dan M. Abdul Karim, "Kontribusi Muhammad bin Qasim dalam Penaklukan Sind", Thaqafiyat, Vol 2 No. 2, 2001, 122.

${ }^{14}$ Hasan Ibrahim Hasan, Islamic History and Culture from 632-1968, penterjemah Djandan Human (Yogyakarta: Kota Kerribang, 1989), 8485.

${ }^{15}$ H. M Elliot, History of India as Told by Its Own Historians11 (London: Trubner 7 co., 1869).

${ }^{16}$ R. C. Majumdar, An Advanced History of India (London : Macmillan and co.Lrd., 1948), 216. Peristiwa ini menyerupai peristiwa penaklukan tentara muslim di Semenanjung Iberia oleh Tariq bin Ziad pada tahun yang sama (713 M) dikuatkan dengan uraian Reinhart Dozy, Spabish Islam (London : Chattos \& Windus, 1913), 32. 
Sepanjang perjalanan menuju tujuan, tidak ada rintangan yang cukup berarti sampai akhirnya mereka bertemu dengan benteng besar dan tinggi. Bentengnya cukup kuat untuk dikalahkan. Ibn Qasim perlu memikirkan strategi lain. Dengan bantuan salah satu pasukan jalanannya, bahasa penulis, Ibn Qasim menemukan satu strategi yang nantinya berhasil membuat lawan menyerah. Adalah strategi pengalihan arus sungai. Dengan alternatif ini, Ibn Qasim menyabotase sungai yang mengalir ke kerajaan sebagai sumber air yang selama ini dipakai dan membuatnya mengalir ke jalur lain.

Walhasil, kerajaan lawan tidak lagi memiliki pasokan air, dan lama-lama lawan menyerah. ${ }^{17}$ Pasukan Ibn Qasim berhasil menaklukkan lawannya dalam tempo empat tahun lebih beberapa bulan.

Sejak saat itu, Muhammad bin Qasim diangkat menjadi Gubernur di sebagian wilayah India dan ini menunjukkan bahwa pada awal abad ke-8 M, Islam sudah hadir di India. Akan tetapi, kisah Ibn Qasim tidak terlalu baik di masa selanjutnya. Karena adanya pertentangan politik antara Hajjaj, yang membesarkan Ibn Qasim, dan Khalifah baru penggantu al-Walid, maka Ibn Qasim terkena imbasnya. Fitnah adalah senjata paling ampuh dalam hal ini.

Pendek cerita, Ibn Qasim digantikan oleh Yazid bin Abu Kabsah al-Suksuki-yang hanya bertahan 18 hari akibat pemberontakan rakyat - dan dilanjutkan oleh saudaranya, Habib al-Muhallab. ${ }^{18}$ Untuk yang terakhir, itu pun tidak se-gemilang masa Ibn Qasim. ${ }^{19}$

${ }^{17}$ Menurut K. Ali, History of India, Pakistan, and Bangladesh (Dhaka: Ali Publications, 1980),17: disebutkan bahwa antara Yazid dan Habib saudara sekandung, anak dari al-Muhallab. Barangkali al-muhallab memiliki nama lain Abu kabshah al-Suksuki.

${ }^{18}$ Mabel Duff mencatat sebagai berikut: 'Muhammad ibn Qasim recalled from Sindh, and put to death by the Caliph Sulaiman. Sindh revolting on the recall of Muhammad, Sulaiman appoints Yazid ibn Abu Kabshah al-Sukuki governor. He dying 18 days afer his arrival, is suceded by Habib ibn al Muhallaf who subdues Alor', C. Mabel. Duff, The Chronology of India: From the Earleest Times to the Beginning of the Sixteenth Century, (Whitehall Gardens: Archibald Constable \& Co., 1899), 61.

${ }^{19}$ H.M. Elliot, H. M, History of India as Told by Its Own Historians 11, (London: Trubner 7 co., 1869), 21-24, K. Ali, History of India, Pakistan, and Bangladesh, (Dhaka: Ali Publication, 1980), 19, dan A. K. M. Abdul Aleem, Bharate Muslim Shasan aybaster Itihas: History of Muslim Administration ini India (Dhaka: Bangka Academny, 1976), 10-20. 
Sebagai tambahan, pada masa selanjutnya, Khalifah Umar bin Abdul Aziz (717-720 M), dikirimlah pasukan lagi untuk meninjau kondisi di India. Khalifah Umar bin Abdul Aziz menunjuk Amru bin Muslim al-Bahalli. Selama Amru di daerah Sind (atau India sekarang) dan Multan terpantau banyak dari orang Hindu yang memeluk Islam. Kemudian, pada masa khalifah Hisham bin Abdul Malik, invasi dilanjutkan dan berhasil sampai menembus batas wilayah Gujarat, Katiawar, Ujjain, Bharoc, dan sebagainya. Situasi pasang-surut seperti ini berlanjut sampai akhirnya lahirlah Dinasti Ghazni.

3) Interaksi pada Dinasti Ghazni

Terhitung sejak masa Nabi sampai abad ke-10 M, seseorang bisa melihat adanya interaksi yang tidak sederhana antara Islam Arab dan India. Beberapa raja dari Muslim pun sudah silih berganti menggantikan kepemimpinannya di India, meski India yang dimaksud di sini masih sebagian kecil. Sebagian besar wilayah India masih dikuasai oleh kerajaankerajaan Hindu kecil sampai akhirnya pada abad ke-11 M, kisahnya berbeda. Adalah ketika pemerintahan Islam mulai beralih dari Abbasiyah — selepas Umayyah — ke Turki.

Sebelum melangkah lebih jauh, penulis mencoba untuk memberi sekilas pandangan tentang pergeseran dari Dinasti Umayyah ke pemerintahan yang berpusat di Turki. Pada awal ketika Abbasiyah berhasil menggulingkan Umayyah dengan bantuan kelompok Syiah, pemerintah memang masih stabil. Ini berjalan selama seratus tahun lebih sampai akhirnya menginjak abad ke-11 M, kegoncangan terjadi. Karena minimnya kualitas dari Raja, banyak wilayah-wilayah bagian dari Dinasti Abbasiyah memutuskan untuk merdeka sendiri dan menjadi kerajaan mandiri. Beberapa dari daerah yang memisahkan diri tersebut antara lain Spanyol, Portugal, Mesir, Persia, dan Turkistan. Dua daerah terakhir bahkan memilih untuk perlahan menggerogoti kesultanan pusat Abbasiyah. ${ }^{20}$

${ }^{20}$ Istiaq Husain Qureshi, The Administration of The Sultanate of Delhi (New Delhi: Oriental Books Reprint Co,1971), 24. 
Salah satu kebijakan yang menjadi boomerang dari Dinasti Abbasiyah akhir adalah diangkatnya tidak sedikit perwira dari Turki. Awal-awal, sebab juga permulaan, mereka masih bisa dikontrol, tetapi lama-lama apalagi ketika mereka tahu bagaimana kesultanan sungguh rentan, mereka jadi susah dikontrol. Salah satu nama yang masih dipercaya oleh Khalifah resmi waktu itu adalah Mahmud. Mahmud mendapatkan kepercayaan dari Khalifah al-Qadir Billah untuk melakukan ekpedisi ke daerah India. Kesempatan ini tidak disia-siakan oleh Mahmud, mengetahui juga ia adalah pribadi yang ambisius dan pekerja keras.

Berkenaan dengan ekspedisi Mahmud ke India, para pakar berbeda pendapat tentang jumlah jelajahnya. Sebagian bilang dua belas kali, sebagiannya tujuh belas. Terlepas dari perbedaan tersebut, yang jelas perjalanan Mahmud ke India cukup membekas baik di benak Kesultanan Abbasiyah dan masyarakat India. Adapun maksud dari masyarakat India di sini adalah memuat baik Muslim yang sudah beranak-pinak di sana atau pun masyarakat Hindu. Mahmud melakukannya sejak awal abad ke11 sampai tahun $1026 \mathrm{M}$ dan dalam tempo itu, ia berhasil menguasai Punjab.

Berhenti sejenak di sini, ada yang penting untuk penulis munculkan ke permukaan yaitu bagaimana antara ketenaran yang didapat Mahmud dan daerah yang berhasil ia renggut. Pertanyaannya, di balik popularitasnya itu mengapa hanya ada satu daerah yang dikuasai. Pertanyaan ini memicu selisih pendapat tentang apa sejatinya motif Mahmud dalam ekspedisinya ke India. Untuk ukuran sosok yang sampai mendapatkan gelar Yamin al-Daulah dan Amin al-Millah dari Khalifah al-Qadir Billah mengapa hanya Punjab yang berhasil didominasi. $^{21}$ Mungkinkah ini menyisakan tujuan lain dari ekspedisi Mahmud ke India?

${ }^{21}$ Zahiruddin Muhammad Babur, Babur Nama, terjemahan John Lexden dan William Erskine, Babur.Memories of Zahiruddin Muhammad Babur (London: Oxford University Press, 1921), 238-239 dan Hamka, Sejarah Umat Islam (Jakarta: Nusantara, 1961), 477-478. 
Para sejarawan berbeda pendapat tentang tujuan perjalanan Mahmud dalam tiga hal, yaitu politik, ekonomi, dan agama.

Pertama lebih tentang bagaimana alasan Mahmud ke India adalah untuk persoalan politik seperti diplomasi atau malah perluasan daerah kekuasaan. Ini terbukti dari adanya pasukan Mahmud yang beragama Hindu. Andai motifnya agama, jelas ini tidak akan terjadi.

Kedua lebih pada kenyataan bahwa di India banyak sekali hal yang di daerah Islam tidak ada, seperti permata dengan aneka warna dan emas jenis tertentu. ${ }^{22}$

Ketiga tampak dari beberapa ungkapan Mahmud yang cenderung pada penyebaran ajaran Islam atau monoteisme dan meminggirkan politeisme penyembahan terhadap tuhan-tuhan, berhala. Sebagai tambahan, yang jelas dari adanya perbedaan analisis atas motif Mahmud, dalam kurun 26 tahun ekspedisi di India, Mahmud berhasil mendirikan wilayah kekuasaan sendiri di Ghazni yang sebab inilah ia disebut sebagai Mahmud Ghaznawi.

Hasil-hasil invasi Mahmud, telah disebutkan sebelumnya bahwa Sultan Mahmud melakukan tujuh belas kali ekspedisi ke India dan menaklukkan banyak tempat. Hampir seluruh wilayah India Utara jatuh ke tangannya. Tetapi jika ekspedisinya ke India dianalisis satu persatu, akan tampak bahwa hasil-hasil kemenangannya tidak permanen. Satu-satunya hasil permanen dari ketujuh belas ekspedisinya adalah penaklukkan Punjab (termasuk Multan). Banyak tempat yang dapat ditaklukkan, tetapi hanya sedikit yang dikuasai secara permanen dalam satu kerajaan Ghazni.

Memang, ketika Mahmud masih hidup, ada beberapa daerah yang koperatif dengan dinasti Ghazni, tetapi selepas Mahmud wafat semuanya berubah. Mereka mulai menggeliat dan kembali mendirikan wilayah bagian kekuasaannya kembali. Jadi, dari banyak hal, satu-satunya daerah peninggalan Mahmud adalah Punjab.

${ }^{22}$ W. Montgomery Watt, The Majlesty That was Islam, terjemahan Hartono Hadikusumo, Kejayaan Islam: kajian kritis dari Tokoh Orientalis (Yogyakarta: Tiara Wancana, 1990), 213-214. K. Ali, History of India, Pakistan, and Bangladesh (Dhaka: Ali Publications, 1980), 31. 
Meski demikian, pengaruh invasi Sultan Mahmud dalam sejarah India dari segi politik, ekonomi, dan budaya tidak dapat diabaikan. Secara politis, ekspedisi-ekspedisi ini membuka jalan bagi penaklukkan India di masa mendatang oleh pasukan Islam.

Keberhasilan Sultan Mahmud menunjukan kelemahan sistem politik dan militer India dan membangun superioritas pasukan Islam terhadap orang-orang Hindu dalam segi seni berperang, disiplin, dan pengabdian kepada tugas. Secara ekonomis, invasi-invasi ini mengakibatkan pengurasan habishabisan atas kekayaan India yang sudah terakumulasi sejak lama. Sementara mengangkibatkan India jauh lebih miskin, inivasiinvasi ini memberikan sumbangan besar terhadap kejayaan dan kebesaran Ghazni dan memungkinkan Sultan untuk membiayai skema-skema perang dan perdamaiannya. Secara budaya, invasi Sultan Mahmud membawa peradaban orang-orang Hindu dan Islam ke arah hubungan yang dekat serta terjadinya saling tukar ide- pemikiran antara penakluk dan yang dilakukan.

Pada 1027 M, Mahmud jatuh sakit dan meninggal pada usia 60 tahun. Muhammad, salah satu anakny naik tahta menggantikan Mahmud. Muhammad tidak diberi kesempatan lama untuk memerintah. Saudara kandung Muhammad, Mas'ud, menggeser posisi Muhammad sebagai Sultan Ghazni. Di masa pemerintahan Mas'ud, Dinasti Ghazni melebarkan sayapnya dan menaklukkan dua daerah baru, Oud dan Benaras, dan ini menjadi petanda akhir dari kekuatan Dinasti Ghazni di India. Sepeninggal Mas'ud tidak ada lagi penaklukkan. Tidak ada lagi raja-raja yang bermental dan tangguh. Perubahan di India menyisakan penguasa-penguasa Muslim di Ghazni yang hanya mampu mengembik, mengembik, dan mengembik. Kisah akhirnya, sebagaimana kerajaan lainnya yang melemah, berujung pada kehancuran. 
4) Interaksi pada Dinasti Ghuri

Berdirinya dinasti Ghuri banyak menyisakan kisah sendu. Peperangan menjadi hidangan selama berpuluh tahun, mengalir dari generasi ke generasi mengatasnamakan harga diri jika bukan balas dendam. Sengketa panjang ini dimulai dari ketika salah satu pemimpin wilayah Ghuri, Qatbuddin, dihukum mati oleh pengganti Sultan Mahmud, Sultan Bahram. Hukuman tersebut disebabkan oleh sikap masyarakat Ghuri yang sering menunjukkan sikap keberatan dengan kebijakan kesultanan Ghazni sepeninggal Sultan Mahmud. Jadi, sebagai langkah untuk menyetabilkan suasana, Sultan Bahram memutuskan memberi pimpinan wilayah Ghuri hukuman mati.

Mendapati kabar tersebut, masyarakat Ghuri tidak bisa menerima apalagi mereka tahu bahwa kelompok Ghuri selama kepemimpinan Sultan Mahmud memiliki kontribusi yang tidak sedikit. Termasuk yang tidak terima adalah Saifuddin, saudara dari Qatbuddin. Saifuddin, selang beberapa saat selepas saudaranya terbunuh, melakukan aksi balas dendam. Dengan pasukan yang sudah dipersiapkan, Saifuddin pergi ke Kesultanan. Pertempuran pecah dan Sultan Bahram berhasil dipukul mundur, meski belum terbunuh.

Namun, tidak lama kemudian, Sultan Bahram kembali menyerang Saifuddin. Kali ini kekuatan yang dibawa Bahram jauh lebih kuat. Hasilnya, Saifuddin kalah dan malah Bahram berhasil membunuhnya. Tidak berhenti di sini, saudara Saifuddin yang lain, Alauddin, mengetahui dua suadaranya sudah dibunuh oleh orang yang sama, berikrar pada dirinya untuk menghancurkan Kesultanan Ghazni.

Jarak beberapa tahun, ketika Alauddin sudah benar-benar merasa siap dengan segenap pasukan dan strategi, akhirnya ia pergi ke Kesultanan. Alauddin kali ini berhasil membalaskan dendam dua saudaranya. Beberapa bangunan megah tak ayal menjadi korban kemarahan Alauddin. Perang masih membara sampai pada cucunya Sultan Bahram, Khusrau Malik, yang pada akhirnya berhasil dikalahkan oleh Muhammad Ghuri pada 1191 M dan di sinilah akhir kisah dari Dinasti Ghazni sebagai kesultanan Islam di India. 
Secara kasar, selepas Dinasti Ghazni tenggelam, wilayah Ghuri naik dengan Muhammad Ghuri atau Muizzudin Muhammad alias Ghiyasuddin. Muhammad Ghuri tidak lain adalah sepupu dari Alauddin, sehingga tidak terlalu mengherankan kenapa dia yang naik tahta. Tidak berbeda pula dengan Alauddin, Ghuri adalah sosok yang keras, ambisius, dan bercita-cita untuk mengusai. Walhasil, di masa pemerintahannya, invasi kembali terjadi dan masih dengan daerah kawasan India sebagai daerah bidikan.

Ada beberapa faktor yang membawa Muhammad Ghuri untuk mengarahkan tentaranya ke India. Pertama sebab India adalah wilayah yang lebih mudah untuk ditaklukkan. Kedua ini adalah misi pemberantasan. Sisa-sisa pasukan Ghazni yang sudah ditumpaskan pergi ke Punjab untuk minta perlindungan, sehingga tentu untuk menguasai Punjab merupakan kepentingan tersendiri.

Penilaian Muhammad Ghuri, Muhammad Ghuri adalah politisi besar dan negarawan dengan pandangan jauh ke depan. Ia merealisasikan secara penuh kondisi politik India yang bobrok dan karenanya memutuskan untuk mendirikan sebuah pemerintah permanen. Sultan Mahmud tidak berminat pada penaklukan permanen di India. Ia datang, menaklukan dan kemudian kembali ke negerinya sendiri. Ekspedisinya ke India tidak menyisahkan hasil-hasil permanen kecuali dalam bentuk penaklukkan Punjab. Muhammad Ghuri dalam hal ini cukup berbeda. Ia menaklukkan negeri itu dan mengkonsolidasikan wilayah yang ditaklukkannya.

Tujuan pertama baginya yakni untuk mendapatkan suatu kekuasaan Muslim permanen di India dan ia selama waktu hidupnya menyediakan sumber daya yang diperlukan untuk menjalankan kesultanan ini. Di bawah bimbingannya langsung, ia melatih banyak administrator ahli yang makin memperbesar keyakinan dan kerpecayaan dirinya.

Quthbuddin Aibak, salah satunya. Aibak diberi tugas untuk melanjutkan penaklukkan India setelah pertempuran Tarain II dan ia menjalankan tugas tersebut dengan reputasi yang baik. 
Meskipun hidup Ghuri berakhir dengan tragis, tradisitradisi yang dibangun olehnya diteruskan dibawah kepemimpinan para penggantinya yang ahli, termasuk para budak Turki yang memerintah setelahnya. Ia hidup dalam sejarah tidak hanya sebagai seorang penakluk, tetapi juga sebagai seorang pendiri kesultanan. Karena itu, Muhammad Ghuri secara mutlak disebut sebagai pendiri kesultanan muslim di India.

Muhammad Ghuri adalah salah satu tokoh yang menonjol pada masa India pertengahan. Seorang yang penuh dengan kebanggaan, usaha, dan semangat. Ia melakukan negosiasi dengan egara-negara Hindu secara terus-menerus selama beberapa tahun dan pada titik ini ia menunjukan kehebatan dan ketekunan yang sangat luar biasa. Hal ini bukanlah sumbangan kecil.

Antara Muhammad Ghuri dan Sultan Mahmud, boleh disebut Muhammad Ghuri dan Sultan Mahmud adalah dua tokoh penting di India pada era pertengahan. Mereka prajurit yang penuh energi dan menyerang India berulang kali. Suatu penelitian yang hati-hati dan mendalam terhadap pencapaian dan karakter mereka menunjukan bahwa mereka berbeda, tapi ada sisa-sisa persamaan.

Dari Mahmudnya, ia merupakan jendral yang lebih besar dari Muhammad Ghuri. Karir militernya lebih cemerlang dan memimpin tujuh belas ekspedisi ke India, pun tidak pernah kalah. Adapun Muhammad Ghuri lebih ke prajurit biasa yang kerap harus menelan kekalahannya. Di level ini, Ghuri memang jauh di bawah Mahmud, tetapi pada aras sikap terhadap hasil penyerangan, Ghuri tidak tertandingi. Ia tidak saja berhenti dengan apa yang sudah didapat, tetapi juga turut memikirkan pembangunan ke depan.

Beberapa penaklukkan Ghuri, meski tidak sepadat Mahmud, dibarengi dengan keberanian untuk konsolidasi. Dengan adanya konsolidasi tak ayal prinsip-prinsip Islam menjadi turut tertanamkan di daerah taklukkannya. Satu lagi: keduanya berbeda di bidang selera. Mahmud bisa dibilang lebih menyukai bidang pendidikan, sedangkan Ghuri seni berpolitik. Tidak sedikit lingkar diskusi seni didirikan oleh Mahmud. 


\section{Islam di India: Jalur Informal}

Selain dengan invasi dan kesepakatan antar-daerah, Keislaman di India juga mengalami penetrasi dari jalur swasta. Ada tiga jalan secara umum yang bisa penulis petakan di sini, yakni jalur perdagangan, jalur dakwah atau sufi-ulama, dan perkawinan.

1) Perdagangan

Bukti yang paling mencolok dari adanya interaksi perdagangan ini adalah ditemukannya koin yang dipakai masyarakat Muslim di bawah pemerintahan Khalifah Harus alRasyid pada 788 M di Mainamati dan Paharpur, India Timur. Seperti apa pun spekulasi yang muncul dari ditemukannya koin tersebut, yang jelas bahwa dua bangsa di atas sudah pernah berinteraksi dagang pada masa lalu. Akibatnya, karena relasinya dagang, maka tentu di sini hubungannya tidak sedang dalam ketegangan atau peperangan - saja - tapi sebaliknya. ${ }^{23}$

Menurut sumber yang penulis dapatkan, perdagangan antara dua belah pihak mendapatkan momentumnya ketika di masa Dinasti Ghuri, terlebih ketika Dinasti tersebut sudah mengusai Delhi. Pada patahan sejarah ini, banyak pedagang Arab pergi ke India untuk menawarkan barang yang tidak ada di India. Banyak dari mereka biasanya tidak saja berdagang, tetapi sekaligus mengenalkan tradisi Islam ke masyarakat India. Sebagai catatan saja, salah satu komoditas yang cukup diminati adalah kuda.

2) Sufi dan Ulama

Di samping para panglima, ada juga sufi dan ulama yang mengenalkan keislaman ke India. Salah satu yang populer adalah Abu Yazid Bustami (w. 872 M). Abu Yazid pernah berguru ke India selama beberapa tahun kemudian memilih untuk menetap di Chittagong, India Timur, dan sempat mendirikan pusat penyiaran keislaman atau Khankah.

${ }^{23}$ Imam Ibn Qayyim al-Jauziah, Zad al-Maad fi Hadyi Khair al-Thad Muhammad Khatim al-Nabiyyin wa Imam al Mursali, jilid.iii (Kairo: Mathba'ah al-Mesriyah, 1379 H), 63-99. 
Upaya Abu Yazid ini memberikan sumbangan yang besar bagi berkembangnya agama Islam di India. Banyak orang sekitarnya yang belajar agama dan masuk Islam sampai akhirnya situasi harus membuat Abu Yazid untuk kembali Bustam karena ibundanya sakit.

Sepeninggal sang ibu, Abu Yazid tidak kembali lagi ke Chittagong, tapi meski demikian, pengaruhnya sudah cukup mengakar, sehingga cukup wajar kenapa di India ada makam dengan ukiran namanya di batu nisan. Terhitung sampai saat ini, ratusan orang ziarah ke makam Abu Yazid dalam satu hari.

3) Perkawinan

Salah satu peristiwa yang memicu adanya pernikahan cukup banyak antara Muslim-Arab dan pribumi India adalah rusaknya kapal dagang Arab karena menabrak Pulau Ramri. Kecelakaan ini menjadikan semua penumpang kapal tidak bisa lagi kembali ke tanah asal, sehingga bagaimana pun harus tinggal untuk sementara di India. Pada mulanya, niat mereka memang sementara, tetapi karena tuntutan kondisi, banyak dari mereka memutuskan untuk menikah dengan pribumi dan menetap di sana.

Memang, silang perkawinan ini tidak lain adalah bentuk lanjut dari adanya relasi dagang yang terbangun antara Arab dan India, tetapi meski demikian dampak yang dihasilkannya berbeda. Jika perdagangan ibaratnya hanya terporos pada materi, maka dengan adanya pernikahan ini, porosnya sudah hati atau keturunan bahasa lainnya. Di waktu bersamaan, karena pernikahan, maka otomatis mereka yang menikahi pribumi India, menjadi masyarakat India.

Adapun mengenai kemauan masyarakat India untuk menikah dengan pedagang Arab berhubungan erat dengan keahlian mereka dalam ilmu pengobatan. ${ }^{24}$ Ada yang menyebut bahwa pernikahan terjalin karena adanya semacam hutang budi atau ketertarikan pada umumnya.

${ }^{24}$ Nabi adalah wakil dari Tuhan, Khalifah adalah pengganti Nabi, dan Sultan adalah wakil dari Khalifah. Hal ini berunah setelah ke Khalifahan Abbasiah di Bagdad duhancurkan oleh Hulagu Khan pada tahun 1258 M dan ke Khalifahan dipindahkan ke Mesir oleh Sultan Baybars dari dinasti Mamluk (1261 M) yang memanfaatkan jabatan Khalifah untuk kepentingan politiknya. Sultan Salim dari Turki Usmaniyah menguasa Mesir (1517 M) dan Khalifah terakhir Abbasiah di Mesir dibawa ke Istanbul untuk mengabil alih jabatan Khalifah. Jadi sejak itu penguasa Turki sebagai sultan untuk wilayah kekuasaannya dan Khalifah untuk seluruh dunia Islam. 
Beberapa tabib (untuk menyebut pedagang yang bisa mengobati) memang kerap membuka pelayanan dengan harga yang rendah, malah juga gratis.

Pemandangan seperti ini tentu menarik banyak hati masyarakat India, terutama masyarakat menengah ke bawah. Dari data yang penulis dapatkan, sebagian besar masyarakat India kala itu yang masuk Islam berasal dari kalangan Budha yang terpinggirkan dan Hindu kasta bawah. Satu sisi, ini terjadi karena mereka merasa terbantu dan akhirnya tertarik dengan Islam. Pada sisi lainnya, bisa juga Islam disituasikan sebagai sesuatu yang harus ditebus ketika mereka mendapatkan pengobatan gratis.

\section{E. Asimilasi Budaya}

Persinggungan panjang plus berliku antara budaya IslamArab dan masyarakat India memuncak pada terciptanya keberislaman yang khas. Paling tidak, perpaduan ini bisa dilihat dari tiga bidang, yakni ilmu pengetahuan, seni bangunan, dan bahasa.

1) Ilmu pengetahuan

Di bidang ini, seseorang bisa membuktikan dengan adanya proses penerjemahan buku-buku berbahasa India ke bahasa Arab pada abad ke-8 M. pada saat itu, tidak sedikit pakar dari Baghdad yang sengaja dikirim ke India baik untuk mengenalkan Islam atau pun mempelajari kelimuan yang berkembang di sana. Walhasil, dari pengiriman tersebut, mereka bisa membawa beragam literatur India ke Baghdad untuk diterjemahkan. Beberapa pakar yang pernah ke India antara lain: Amir Khusru (ahli astronomi Arab), Abu Mashar (belajar di pusat kebudayaan Hindu, Benaras) dan Abu Yazid Bustami. Jika diurutkan sejak awal, seseorang bisa dengan mudah mendapatkan gradasinya. Pada masa awal, Dinasti Umayyah dan Abbasiyah, ada tiga buku terjemahan dari India-Arab yang cukup populer, yakni buku Shiddanta karangan Brahma Gupta, Kallah wa Dimna, Shasruta, dan Carak. 
Buku pertama lebih pada isu astrologi dan angka yang judul terjemahannya Tariche Sind Hind. ${ }^{25}$ Buku kedua adalah hasil terjemahan dari buku asli yang berjudul Panca Tantra. Buku ini berisi tentang teknik pengobatan India yang di satu patahan sejarah pernah menjadi pemicu sembuhnya Khalifah Harus al-Rasid dari sakitnya.

Dua buku terakhir lebih ke buku umum dengan banyak muatan mulai dari kisah hewan, kimia, musik, sihir, dan semacamnya. Walhasil, di level ini, seseorang bisa menyebut bahwa Arab cukup berhutang pada India.

Kemudian, pada masa Sultan Mahmud dari Dinasti Ghazni, di sini bisa ditemukan tidak sedikit tokoh yang muncul ke permukaan karena karyanya seperti Firdausi (920-1020), Badiuzzaman al-Hamdani, Abu Bakar al-Khawarizmi, Unsari, alFarrukhli, Asduji, Abu al-Faraj al-Rumi, Mas'udi, Sa'di Salman, dan Sana'i. Dari semua itu yang cukup populer adalah Firdausi, al-Hamdani, dan al-Khawarizmi.

Firdausi adalah penulis buku Shah Nama yang pernah nyaris diberi penghargaan luar biasa dari Sultan, tetapi diurungkan karena ada hasutan dari pihak yang iri padanya, ${ }^{26}$ sedangkan dua tokoh sisanya tidak lain merupakan sosok pengarang yang cukup berpengaruh dalam perkembangan sastra Arab.

Selain mereka ada satu lagi yang tidak boleh dilupakan, yakni al-Biruni dari Khawarism (sekarang wilayah Uzbekistan). Al-Biruni pernah mengarang satu buku yang membahas tentang sejarah dan kondisi geografi India. Judulnya Kitab al-Hind. Di situ, al-Biruni menjelaskan peradaban Hindu dan situasi politik India ketika invansi Mahmud secara netral, simpatik, dan ilmiah. Ia menerangkan pula tentang tradisi ketika seorang istri apabila suaminya meninggal, maka ia harus ikut membakar diri.

25 Elliphenston (Mountstuart), The History of India: The Mohametan Period (London: Jhon Murray, 1857), 260.

26 Abdul Maudud, Muslim Monish: Biographical Sketches of Muslim Intelectuals (Dhaka: Nawroz Kitabistan, 1970), 82-83, Abdul Karim, Bharatiya Upamadeshe Muslim Shashan: Muslim Rule in Indian SubContinent (Dhaka: Bangla Academy, 1974), 26. 
2) Seni dan Bangunan

Bangunan-bangunan yang didirikan oleh Sultan, mencakup istana kerajaan, benteng, masjid, dan tugu orang-orang besar, dirancang dengan perpaduan gaya dari beragam budaya: mulai dari Siria, Bizantium, Hindu, sampai Jaina. Kontak antara Islam dan Hindu menghasilkan evolusi gaya yang kadang-adang disebut Indo-Muslim. Arsitektur Indo-Muslim adalah arsitektur Muslim yang menampilkan detail sifat-sifat tertentu dari seni banguan Hindu. Semakin banyak ahli muslim memasuki India, pengaruh Hindu semakin berkurang sedikit demi sedikit.

3) Bahasa

Dari segi bahasa pun, seseorang bisa merasakan adanya asimilasi. Pada zaman Dinasti Ghaznawi dan Ghuri, para Sultan berbahasa Turki di istana, sedangkan di kantor berbahasa persi. Para tentara, ketika berbelanja ke pasar mengalami kesulitan (masyarakat memakai bahasa Prakrit dan Sansekerta) akhirnya lahir bahasa baru yaitu Urdu. Adapun pengaruh Islam dalam bahasa Sansekerta melahirkan bahasa Bangla. Lahirnya bahasa baru di aras ini murni karena adanya persinggungan bahasa dari dua bangsa yang tidak saling tahu bahasanya satu sama lain. 


\section{F. Penutup}

Pada zaman Nabi, Islam masuk ke India secara penetration pacifique atau melalui hubungan perdagangan di kota-kota pesisir pantai barat dan selatan. Pada waktu itu, kondisi sosial dan politik India sedang rapuh diperparah dengan dengan adanya penindasan kaum kasta Brahmana atas kasta yang lebih rendah dan beberapa pemeluk Budha.

Pasukan Islam-Arab menjalin interaksi dengan India koinsiden dengan kerapuhan di India tersebut. Walhasil, mereka tidak mendapatkan rintangan yang cukup berarti ketika masuk ke wilayah India. Ibn Qasim datang ke India dengan membawa harapan bagi keselamatan para tertindas dan sejak saat itu keislaman perlahan tersebar ke wilayah India.

Terselipnya motif sosial atau membantu mereka yang tertindas oleh kasta atas, di balik alasan politik, agama, dan ekonomi menjadikan invasi ke India berhasil telak. Tidak saja penguasaan bahkan yang dicapai, tetapi juga pengelolaan daerah yang sudah dikuasai. Walhasil, persis di titik ini perpaduan budaya antara Islam-Arab dan India terjalin dan memuncak pada pranata keislaman yang khas di India.

Ada tiga ranah tempat perpaduan di muka bisa dilihat, yakni buku-buku terjemahan, seni bangunan, dan bahasa. Di India tidak sedikit bangunan yang bergaya antara khas India dan Syria. Dari karangan buku pun, banyak literatur India berhasil dialihbahasakan ke Arab demi tercapainya akses keilmuan di India yang dibutuhkan masyarakat Muslim-Arab. Adapun dari aspek bahasa, disebabkan adanya gesekan antara beragam bahasa yang berbeda-beda di India, maka lahirlah beberapa bahasa baru sebagai akibat natural. 


\section{Daftar Pustaka}

Ahamad, Aziz, Studies in Islamic Culture in The Indian Environment, Oxford: Clarendon Press, 1964.

Aleem, A. K. M. Abdul, BharateMuslim Shasan aybaster Itihas: History of Muslim Administration ini India, Dhaka: Bangka Academny, 1976.

Ali, A Yusuf, The Making of India, London: A \& C Black Ltd., 1925.

Ali, K., History of India, Pakistan, and Bangladesh, Dhaka: Ali Publication, 1980.

al-Jauziah, Imam Ibn Qayyim, Zad al-Maad fi Hadyi Khair alThad Muhammad Khatim al-Nabiyyin wa Imam al Mursali, jilid.iii, Kairo: Mathba'ah al-Mesriyah, 1379

Arnold, Edwin, India Revisited, London: Trubner and Co., 1886.

Babur, Zahiruddin Muhammad, Babur Nama, terjemahkan John

Lexden dan William Erskine, Babur: Memories of Zahiruddin Muhammad Babur, London: Oxford University Press, 1921.

Beveridge, Henry, A Comprehensive Hostory of India I, London: Blackie \& Son, 1862.

Deartemen Agama Republik Indonesia, al-Quran dan Terjemahnya, Jakarta: Proyek Penggandaan Kitab Suci al-Qur'an, 1985.

Dozy, Reinhart, Spabish Islam, London: Chattos \& Windus, 1913.

Duff, C. Mabel, The Chronology of India: From the Earleest Times to the Beginning of the Sixteenth Century, Whitehall Gardens: Archibald Constable \& Co., 1899.

Elliot, H. M, History of India as Told by Its Own Historians 11, London: Trubner 7 co., 1869.

Elliphenton (Mountstuart), The History of India: The Mohametan Periods, London: Jhon Murray, 1857.

Gibb, N.A.R., "Ibn Batuta Travels in Asia and Afrika 13251354”, dalam Sir E. Denison Ross dan Eileen Pwer The Broadway Travelers, London: Routledge \& Kegan aul Ltd., 1929.

Hamka, Sejarah Umat Islam, Jakarta: Nusantara, 1961.

Hasan, Hasan Ibrahim, Islamic History and Culture from 6321968, Penterjemah Djandan Humam,Yogyakarta: Kota Kembang, 1989 
|Sadari

Hussaini, S.A. Q., Arab Administration. Madras: Soldent \& Co., 194.

Ikram, S. M, Muslim Civilization in India, ed. Ainslie T. Embree, New York: Columbia University Press 1964.

Internet, Truth About Dahir San, http:www.osl.cs.vivc.Edu/jamali/Sindh/story/node.

Itzkowits, Norman, Ottoman Empire and Islamic Tradition, New York, Alfred A. Knopf, 1972.

Karim, Abdul, Bharatiya Upamadeshe Muslim Shashan: Muslim Rule in Indian Sub-Continent, Dhaka: Bangla Academy, 1974.

Karim, M. Abdul, "Kontribusi Muhammad bin Qasim dalam Penaklukan Sind", Thaqafiyat, Vol 2 No. 2, 2001.

Karim, Muhammad Reza I, Arab Jatir Itihas: History of the Arabs, Dhaka: Bangkla Academy, 1972.

Kaya, K. P., Muslim Missionaries in South India, terjemahan Abdul Quasem Bhuiyan Dakkhin Bharta Muslim Mishionari, Faridpur: Islamic Cultural Centre, 1980.

Majumdar, R. C., An Advanced History of India, London: macmillan \& co.Ltd., 1948.

Maudud, Abdul, Muslim Monish: Biographical Sketches of Muslim Intelectuals, Dhaka: Nawroz Kitabistan, 1970.

Musa, Mansur, Bangladesh, Dhaka: Department of Bangla, Dhaka University, 1974.

Nadavi, Maulana Abdul Hasan Ali, Muslim and Indian Cilvilaization, Terjemah, Nainar, S. Husayan, Islam di India dan hubungan-hubunganya dengan Indonesia, Jakarta: Information Service of India, 1965.

Nadavi, Maulana Abul Hasan All, Muslim and Indian Civilaixation, terjemah siddiq Ahmed, Upamahadeshio Shavvatai Muslim Abodan, Dhaka: The Islamic Fondation Bangalesh, 1980.

Nadavi, Maulana Abul Hasan All, Muslim and Indian Civilaizaition, terjemahan Siddiq Ahmed, Upamahadeshio Shavvatai Muslim Abodan, Dhaka: The Islamic Foundation Bangalesh, 1980.

Nasa'i, Sunan al-Nasai, Kitab al-Jihad, Beirut: Daar al-Fikr, 1930.

Percetakan Taman Siswa, Buku Peringkatan Taman Siswa 60 Tahun 1922 1982, Yogyakarta: 1982. 
Sadari, et.al, "Religious Local Wisdom For Strengthening Social Harmony: Study in Banyumas Indonesia and New Delhi India", in Proceedings of the 2nd International Colloquium on Interdisciplinary Islamic Studies (ICIIS) in Conjunction with the 3rd International Conference on Quran and Hadith Studies (ICONQUHAS), 2020.

Qureshi, Istiaq Husain, The Administration of The Sultanate of Delhi, New Delhi: Oriental Books Reprint Co,1971.

R. C. Majumdar, An Advanced History of India, London: Macmillan and co.Lrd., 1948.

Sukamto, Soerjono, Sosiologi Suatu Pengatar, Jakarta: PT. Raja, 1994.

Talib, Abdul Manan, Bangladeshe Islam, Dhaka: Adhunik Prokashani, 1980.

Watt, W.Montgomery, The Majlesty That was Islam, terjemahan Hartono Hadikusumo, kejayaan Islam: kajian kritis dari Tokoh Orientalis, Yogyakarta: Tiara Wancana, 1990.

Wheller, R. E. M., Five Thousands Years of Pakistan, London: Cristopher Jhonson 1950. 